Case Report

\title{
Neonatal non-immune hydrops due to large placental chorioangioma -a treatable cause of hydrops
}

\author{
Jadhao A. ${ }^{1}$, Rakesh K. ${ }^{2}$, Singh H. ${ }^{3}$, Maddireddi A. ${ }^{4}$ \\ ${ }^{1}$ Dr. Arjun Jadhao, Fellow in Neonatology, Apollo Spectra Hospital, Paradise Circle, Hyderabad, Telangana, ${ }^{2}$ Dr. Rakesh \\ Kotha, Assistant Professor, ${ }^{3}$ Dr. Himabindu Singh, Professor, ${ }^{4}$ Dr. Alimelu Maddireddi, Professor, all authors are \\ affiliated with Department of Neonatology, Niloufer Hospital, Hyderabad, Telangana, India.
}

Corresponding Author: Dr. Rakesh Kotha, Assistant Professor, Department of Neonatology, Niloufer Hospital, Hyderabad, Telangana, India. E-mail: dr.rakeshkotha@gmail.com

\begin{abstract}
The term non-immunologic hydrops fetalis (NIHF) defines an edematous fetus with fluid collections in some usually two or all serous cavities that does not have erythroblastosis fetalis from isoimmunization. Ballantyne described the first case of non-immune hydrops. In 1943 Dr Edith Potter published the first description of NIHF. Hydrops Fetalis is considered as a prenatal form of cardiac failure. Hydrops may present as a stiffness of one limb due to edema (present case) to severe generalized anasarca with bilateral pleural effusion. Usually non-immune hydrops associated with severe morbidity and mortality. NIHF not only caused by fatal fetal causes like Chromosomal, alpha thalassemia, infections and cardiac causes but also caused by placental causes like twin to twin transfusion syndrome and placental tumours like placental chorioangioma, among these last entity usually have good prognosis if we managed properly in utero or at the time of delivery and early postnatal days. Some cases of non-immune hydrops amenable to treatment and will have better prognosis like chylothorax, CCAM, Supra Ventricular Tachycardia (SVT), bladder obstruction and hydrothorax.
\end{abstract}

Keywords: Non-immune hydrops, Placental chorioangioma, Neonate, Perinatology, Fetal cardiac failure, Fetal anemia

\section{Introduction}

A newborn with hydrops has an abnormal accumulation of fluid. After introduction of anti-D immunoglobulin immune hydrops decreased to $6-10 \%$ of all cases of hydrops. Edema in non-immune hydrops usually caused by Elevated central venous pressure (CVP), Decreased lymphatic flow Capillary leak and anemia [1]. Severe anemia usually causes a Hydrops due to high output cardiac failure. If cause of hydrops not in baby perse like alpha thalassemia and chromosomal anomalies, usually better prognosis expected, if we intervene timely. Large Placental chorioangioma which is the most common benign tumour also causes hydrops in fetus [2]. Because of advancement in perinatology now a days chorioangioma usually managing in utero by laser vascular ablation. Here we are presenting a case of large placental chorioangioma. Baby delivered at 30 weeks due to severe doppler abnormalities with severe anemia, hydrops, and consumptive coagulopathy.

\section{Case Report}

34 years primi IVF conception after 11 years admitted at 30 weeks of gestation in view of preterm labour, outside scans showed placental chorioangioma though they have been advised fetal therapy they differed. Antenatal steroids started, fetal scans showed fetal hyperdynamic circulation and doppler findings in favour of severe anaemia and hydrops (skin edema of left arm $>5 \mathrm{~mm}$ ). Noticed a large vascular tumour at the fetal side of placenta about $5 \mathrm{~cm}$ in diameter [Figure 1]. Emergency LSCS done in view of abnormal dopplers particularly middle cerebral artery and placenta previa. Baby was pale, severe ecchymotic patches noticed all over the body and severe subgaleal bleed due to consumptive coagulopathy [Figure 2, 3]. Baby cried immediately after birth but soon baby developed gasping efforts. Baby intubated immediately and given gentle ventilation. Compatible packed cells, Fresh plasma and platelets given until consumptive coagulopathy

Manuscript received: $4^{\text {th }}$ September 2019

Reviewed: $14^{\text {th }}$ September 2019

Author Corrected: $20^{\text {th }}$ September 2019

Accepted for Publication: $25^{\text {th }}$ September 2019

Pediatric Review: International Journal of Pediatric Research Available online at: www.medresearch.in 511|P a g e 


\section{Case Report}

resolved in baby confirmed by lab by micro sampling. Intravenous Inj Vit $\mathrm{k}$ given. Congestive cardiac failure treated with diuretics and inotropic support and through proper ventilatory settings. As baby developed jaundice within hours treated with phototherapy. Gradually baby extubated. Baby started on partially TPN (Total parental nutrition) particularly aminovien, gradually baby reached full enteral feeds. During the course baby received necessary preterm care [Figure 4]. At the time of discharge baby was gaining adequate weight and on full paladai feeds. Placental tumour also confirmed by pathologist as chorioangioma.

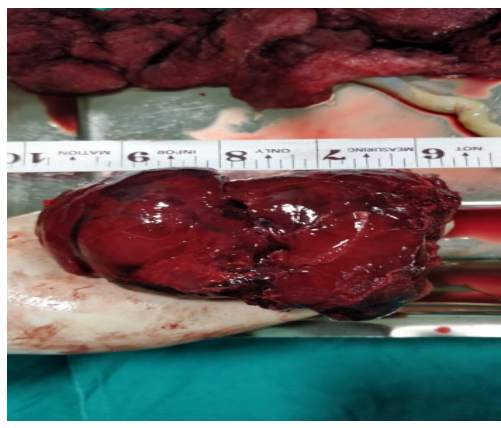

Fig-1: Large placental chorioangioma.

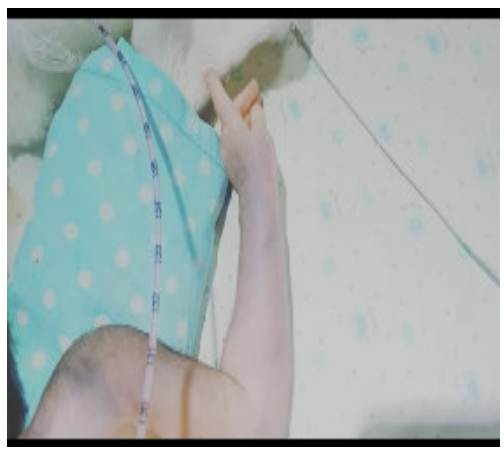

Fig-3: Ecchymotic patches over the shoulder and severe pallor.

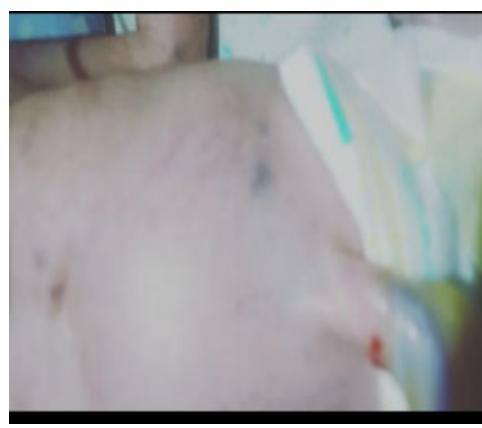

Fig-2: Ecchymotic patches over the abdomen.

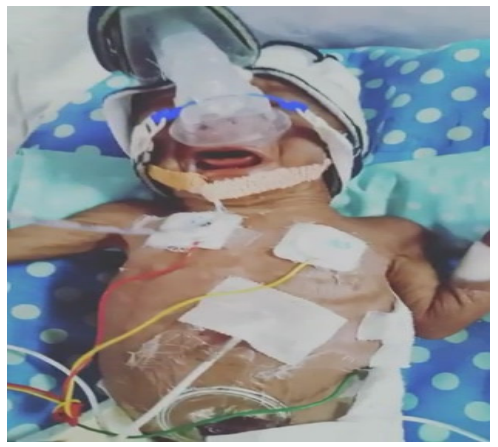

Fig-4: Same baby at 10 days of life.

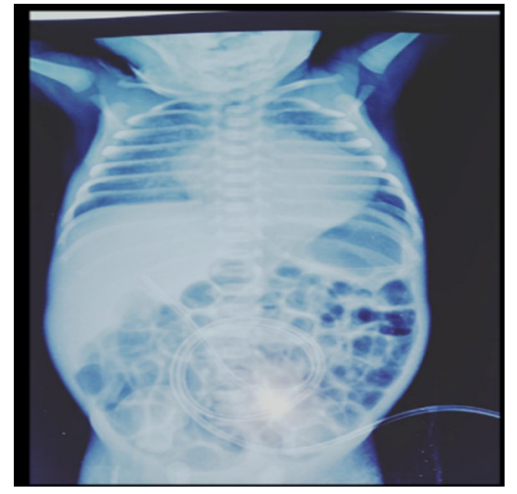

Fig-5: X ray at 2 hours of life showed cardiomegaly with CT ratio 0.79 .

\section{Discussion}

After invention of Rh (D) immunoglobulin in 1968, Cases of immune hydrops dramatically decreased as it prevents above $94 \%$ of alloimmunization at present, non-immune hydrops accounts for ninety percent of cases [3]. Non-immune fetal hydrops is diagnosed when there is fluid accumulation in more than one extravascular space. Non-immune fetal hydrops is not a diagnosis it is a clinical phenotype. The identification of hydrops by ultrasound is very frustrating to the family and physicians because it requires extensive search for the etiology. Even after undergoing a long list of testing, a good number of cases remain with no clear 


\section{Case Report}

diagnosis. More recently, investigators have shown that with thorough investigations, an underlying cause can be identified in up to $84 \%$ of such fetuses [4]. In addition, the prognosis traditionally been reported as poor with perinatal loss of $70-90 \%[5,6]$.

Hydrops are caused by Fetal, maternal and placental/cord abnormalities. Overall cardiac abnormalities, chromosome abnormalities, and infections were the most common causes of NIHF. In Taiwan, Thailand, and other Southern Asian regions, where the Hb Bart's disease is the main cause for NIHF.

In Brazil one fourth of cases caused by infections. Pathophysiology of hydrops simply net efflux of water from capillary plasma to interstitial tissues or abnormality in starling forces. Greater capillary permeability, more compliant interstitial compartment, and greater influence of venous pressures on lymphatic return in neonates favours the hydrops.

In chromosomal abnormalities due to narrow chest and decreased movements block the lymphatic drainage in early stage of gestation, cardiovascular and haematological causes cause hydrops after 20 weeks when usually sudden increase in hematocrits usually occur. Gatrointestinal and renal causes explained by synthesis and loss of albumin [7].

Though we are here presenting a treatable cause baby parents not in favour of fetal therapy as advised by peripheral doctors when they reached here all Doppler abnormality were occurred which leads to immediate delivery. Placental chorioangioma is the most common benign tumour of placental [2]. Sonographically first diagnosed by Asokan et al [8].

Vascular channels similar to fetal vessels appeared in sonography, by this finding usually differentiate this tumour from others. Chorioangioma usually arises about $16^{\text {th }}$ day of fertilization, though there was no documentation of tumour in first trimester.

The pathogenesis of this benign tumour explained by hypoxia and genetics are factors in some studies [9]. Maternal complications include premature labor, polyhydramnios, abruptio placenta, preeclampsia, and postpartum hemorrhage.

Fetal complications include preterm birth, intrauterine growth restriction, fetal congestive cardiac failure, fetal hydrops, fetal anemia, fetal thrombocytopenia, DIC and intrauterine fetal death [10].
Severe fetal anemia in our case, it was $3 \mathrm{~g} / \mathrm{dl}$ usually explained by fetomaternal hemorrhage and microangiopathic hemolytic anemia because of entrapment and destruction of fetal erythrocytes in the vascular network of the chorioangioma. Because of a hyperdynamic circulation as a result of arteriovenous shunting polyhydromnious, fetal polyuria, and maternal mirror syndrome will occur. Mirror syndrome may represent a form of preeclampsia with generalised fluid overload [11].

Severe anaemia and increased venous return to the heart contribute to the cardiac enlargement [Fig;5] [12, 13]. The hyperbilirubinemia could have developed due to degradation of the injured erythrocytes.

serial ultrasound and Doppler examinations are warranted to detect early features of fetal congestive heart failure [14]. Treatment by intrauterine blood transfusion was considered more beneficial to the fetus than preterm delivery. Successful transfusion and prolongation of pregnancy and antenatal steroids resulted in the birth of an infant in good clinical condition.

The Society for Maternal-Fetal Medicine has recently published new guidelines to aid in the selection of appropriate prenatal testing [15].

In the literature, there were similar cases of fetal anemia associated with placental chorioangioma and treated by intrauterine blood transfusion have been described [16]. A large chorioangioma causing fetal demise was reported [17]. Similar to our case, large placental chorioangioma with polyhydramnios was reported; the patient went into preterm labor and resulted in death from disseminated intravascular coagulation (DIC) [18]. A case was diagnosed at 36 weeks of gestation with polyhydramnios and without much fetal complications which was managed conservatively, and timely intervention led to good outcome [19]. A complicated case of chorioangiomas managed via laparoscopicassisted laser ablation and embolization had a successful outcome of a term baby [20]. Fortunately, recurrence of chorioangiomas is not well recognized [21].

\section{Conclusion}

Hydrops fetalis caused by secondary causes like large placental chorioangioma due to consumptive coagulopathy is treatable if we intervene timely either in utero or postnatally. Idiopathic causes of hydrops is a good research area. 
Case Report

Funding: Nil, Conflict of interest: None initiated, Permission from IRB: Yes

\section{References}

1. Bianchi DW, Crombleholme TM, D'Alton ME. Fetology: Diagnosis \& Management of the Fetal Patient.1st ed McGraw-Hill Professional 2000; pp 959965.

2. Faes T, Pecceu A, Van Calenbergh S, Moerman P. Chorangiocarcinoma of the placenta: a case report and clinical review. Placenta. 2012;33(8):658-661. doi: 10. 1016/j.placenta.2012.04.012. Epub 2012 May 25.

3. Sohan K, Carroll SG, De La Fuente S, Soothill P, Kyle P. Analysis of outcome in hydrops fetalis in relation to gestational age at diagnosis, cause and treatment. Acta Obstet Gynecol Scand. 2001;80(8):726730. doi: https://doi.org/10.1034/j.1600-0412.2001. 080 008726.x.

4. Bianchi DW, Crombleholme TM, D'Alton ME. Fetology: Diagnosis and management of the fetal patient. McGraw-Hill; 2000. p. 959.

5. Holzgreve W, Holzgreve B, Curry CJR. Non-immune hydrops fetalis-diagnosis and management. Semin Perinatol. 1985;9(2):52-67.

6. Gough JD, Keeling JW, Castle B, Illiff PJ. The obstetric management of non-immune Hydrops. Br J Obstet Gynaecol. 1986;93(3):226-234.

7. Heinonen S, Ryynänen M, Kirkinen P. Etiology and outcome of second trimester non-immunologic fetal hydrops. Acta Obstet Gynecol Scand. 2000;79(1):1518. doi: https://doi.org/10.1034/j.1600-0412.2000. 0790 01015.x.

8. Kesrouani AK, Safi J, El Hajj MA. Rapid evolution of placental chorioangioma: natural progression and outcome. J Ultrasound Med. 2013;32(3):545-547. doi: 10. 7863 /jum.2013.32.3.545.

9. Chen CP, Chern SR, Wang TY, Huang ZD, Huang MC, Chuang CY. Pregnancy with concomitant chorangioma and placental vascular malformation with mesenchymal hyperplasia. Hum Reprod. 1997;12(11): 2553-2556. doi: 10.1093/humrep/12.11.2553.

10. Hosseinzadeh P, Shamshirsaz AA, Javadian P, et al. PrenatalTherapy of Large Placental Chorioangiomas:
Case Report andReview of the Literature. Am J Perinatol. 2015;5(2): e196-e202. doi: 10.1055/s-00351558829.

11. García-Díaz L, Carreto P, Costa-Pereira S, Antiñolo G. Prenatal management and perinatal outcome in giant placental chorioangioma complicated with hydrops fetalis, fetal anemia and maternal mirror syndrome. BMC Preg Childbirth. 2012;12(1):72. doi: 10.1186/ 1471- 2393-12-72.

12. Hadi HA, Finley J, Strickland D. Placental Chorioangioma, Prenatal Diagnosis and Clinical Significance. Am J Perinatol. 1993;10(02):146-149. doi: 10. 1055/s-2007-994648.

13. Bauer CR, Fojaco RM, Bancalari E, FernandezRocha L. Microangiopathic hemolytic anemia and thrombocytopenia in a neonate associated with a large placental chorioangioma. Pediatr. 1978;62(4):574-577.

14. Vaisbuch E, Romero R, Kusanovic JP, Erez O, Mazaki-Tovi S, et al. Three-dimensional sonography of placental mesenchymal dysplasia and its differential diagnosis. J Ultrasound Med. 2009;28(3):359-368. doi: 10.7863/jum.2009.28.3.359.

15. Society for Maternal-Fetal Medicine (SMFM), Norton ME1, Chauhan SP2, Dashe JS. Society for maternal-fetal medicine (SMFM) clinical guideline \#7: nonimmune hydrops fetalis. Am J Obstet Gynecol. 2015; 212(2):127-139. doi: 10.1016/j.ajog.2014.12.018. Epub 2014 Dec 31.

16.Abdalla N, Bachanek $\mathrm{M}$, Trojanowski $\mathrm{S}$, Cendrowski K, Sawicki W. Placental tumor (chorioangioma) as a cause of polyhydramnios: a case report. Int J Womens Health. 2014;6:955-959. doi: 10. 2147/IJWH.S72178. eCollection 2014.

17. Imdad A, Sheikh L, Malik A. A large chorioangioma causing intrauterine foetal demise. J Pak Med Assoc. 2009;59(8):580-581.

18. Kodandapani S, Shreshta A, Ramkumar V, Rao L. Chorioangioma of placenta: a rare placental cause for adverse fetal outcome. Case Rep Obstet Gynecol. 2012; 2012: 913878. doi: 10.1155/2012/913878.

19. Kataria N, Singh A, Bedi PK. Giant placental chorangioma: a rare case report. J Clinic Diagnos Res: JCDR. 2016; 10(4): ED03-ED04. doi: 10.7860/JCDR/ $2016 / 17222.7540$. 


\section{Case Report}

20. Hosseinzadeh P, Shamshirsaz AA, Javadian P, Espinoza J, Gandhi M, Ruano R, Cass DL, et al. Prenatal Therapy of Large Placental Chorioangiomas: Case Report and Review of the Literature. Am J Perinatol. 2015; 5(2): e196-e202. doi: 10.1055/s-00351558829 .
21. Braun T, Brauer M, Fuchs I, Czernik C, Dudenhausen JW, Henrich W, et al. Mirror syndrome: a systematic review of fetal associated conditions, maternal presentation and perinatal outcome. Fetal Diagn Ther. 2010; 27(4): 191-203. doi: 10.1159/ 000 305096. Epub 2010 Mar 27.

\section{How to cite this article?}

Jadhao A, Rakesh K, Singh H, Maddireddi A. Neonatal non-immune hydrops due to large placental chorioangioma- a treatable cause of hydrops. Int J Pediatr Res.2019;6(10):511-515.doi:10.17511/ijpr.2019.i10.03 